ISSN 1392-3196 / e-ISSN 2335-8947

Zemdirbyste-Agriculture, vol. 106, No. 1 (2019), p. 81-86

DOI 10.13080/z-a.2019.106.011

\title{
Trapping peculiarities, flight and mating dynamics of sea buckhorn fruit fly (Rhagoletis batava) in Lithuania
}

\author{
Dominykas ALEKNAVIČIUS, Vincas BŪDA \\ Nature Research Centre \\ Akademijos 2, Vilnius, Lithuania \\ E-mail: dominykas.aleknavicius@gamtc.lt
}

\begin{abstract}
The sea buckthorn fruit fly Rhagoletis batava Hering, 1938 is the most important pest of sea buckthorn (Hippophae rhamnoides L.) and causes big losses of berry yield. Recently, the fly has been rapidly spreading in European buckthorn plantations. The objective of the research was to establish seasonal flight period and diurnal mating period of $R$. batava as well as to compare the efficiency of traps differing in colour and type for trapping fruit flies under field conditions. In Lithuania, annual flight period of $R$. batava lasts approximately six weeks, it starts at the end of June and ceases in August with a peak from the middle of July till the middle of August on average. Both beginning of the flight period and peak activity may vary by about 20 days between years. Mating period of sea buckhorn fruit flies lasts during all light period of a day without a clearly pronounced peak. Among the 7 colours of traps tested, the most attractive was yellow, in which catches were 1.5-7.8 times more abundant compared to the traps of the other colours. The ratio of $R$. batava females caught by McPhail traps was higher compared to that in sticky traps. Location of traps on feminine bushes increases captures of sea buckthorn fruit flies by approximately $50 \%$ compared to the traps located on masculine bushes.
\end{abstract}

Key words: daily mating rhythm, flight season, fruit fly, pest monitoring, trap colour, trap efficacy.

\section{Introduction}

Sea buckthorn (Hippophae rhamnoides L.) is a highly valuable plant because it does not need fertile soils and its berries are especially in demand in food, medicine and cosmetic industry (Li, Schroeder, 1996; Ruan et al., 2007; Bal et al., 2011). Fruit fly Rhagoletis batava (Diptera: Tephritidae) has become the most important pest of sea buckthorn recently. Although most species of genus Rhagoletis are stenophagous (e.g., Mohamadzade Namin, Rasoulian, 2009), as is known, sea buckthorn fruit flies are monophagous and lay eggs exceptionally into berries of sea buckthorn (e.g., Korneyev et al., 2017). Hatched larvae feed on berry flesh and severely damage berries. Those lose their appearance, colour and nutritional as well as economic value. In Siberia, Russia a subspecies $R$. batava obscuriosa Kol. has occurred, which is capable of causing especially severe damage (review in: Stalažs, Balalaikins, 2017) and destroying up to $87-100 \%$ of the berry crop (Shalkevich et al., 2015; Shamanskaya, 2015), thus causing huge economic losses.

During the last decades, $R$. batava has reached Baltic countries (Stalažs, 2014 a; b), and has been spreading towards western and southern Europe (Stalažs, Balalaikins, 2017). To improve the efficiency of monitoring and control of the pest, it is necessary to get a better understanding of its biology and ecology, including flight period and mating activity. As special traps are commonly used for insect pest monitoring, the data on trap type (including colour) suitable for R. batava trapping are needed. Although flies of many species from genus Rhagoletis were attracted by yellow colour (Agee et al., 1982; Yee, 2011; 2012; 2013; Yee, Goughnour, 2011; Toth et al., 2014), this was not the case for $R$. batava, when field testing was carried out using sticky "cloak" (PAL and PALz) type traps (Toth et al., 2016). It still remains to be investigated whether this behavioural phenomenon of $R$. batava species is an exception within the genus Rhagoletis.

The main objective of the present study was to establish seasonal flight period and diurnal mating period of fruit flies $R$. batava as well as to compare the efficiency of traps differing in colour and type for catching fruit flies in sea buckthorn plantations.

\section{Materials and methods}

Experimental site. Field tests were carried out in an organic sea buckthorn plantation located in the vicinity of Stacijava village (N lat. 55.253383, E long. 25.439736), Molètai district, Lithuania. Sea buckthorn (Hippophae rhamnoides L.) berries had not been harvested yet. 
Colour traps. Flat sticky traps of rectangular shape (10 cm wide and $25 \mathrm{~cm}$ long) were made of clear double PVC film (Fellowes, China), $300 \mu \mathrm{m}$ thickness. Colour paper was inserted between the two film layers to provide colour for a trap. White, blue, black, green, red, yellow and transparent (no colour) traps were made. For white trap paper Universal (Navigator, Portugal) $80 \mathrm{~g} \mathrm{~m}^{-2}$ was used, for blue, black, green, red and yellow paper Image Coloration (Antalis, Latvia) $80 \mathrm{~g} \mathrm{~m}^{-2}$ was used. The manufacturer indicated these colours as clear blue, black, meadow green, scarlet and lemon yellow. Both surfaces of the traps were covered by sticky glue (PestiFix, Estonia) developed to fix insects in sticky traps.

The traps were hung in blocks. Six blocks, each containing a full set of all colour traps, were used in total. The distance between the traps was approximately from 1.5 to $2 \mathrm{~m}$, the distance between the blocks was not less than $30 \mathrm{~m}$. Three blocks were hung on masculine plants only (no berries) and three blocks on feminine plants (berries were present). Trapping was carried out in July 2016. Catches were counted and traps were rotated regularly with 3 to 4 days' intervals.

Trap type. Two types of traps were used, both containing yellow surface: flat sticky (Fig. 1A) and McPhail (Pherobank, the Netherlands) traps (Fig. 1B) of cone shape with transparent upper and yellow bottom parts. The latter traps are recommended for trapping fruit flies (Pherobank catalogue, https:/www.pherobank. $\mathrm{com} /$ catalog-item/fruitfly-and-wasp-trap-mcphail-inclcage-33202.html). To fix the insects trapped, $1 \% \mathrm{NaCl}$ water solution was added into the bottom vial.
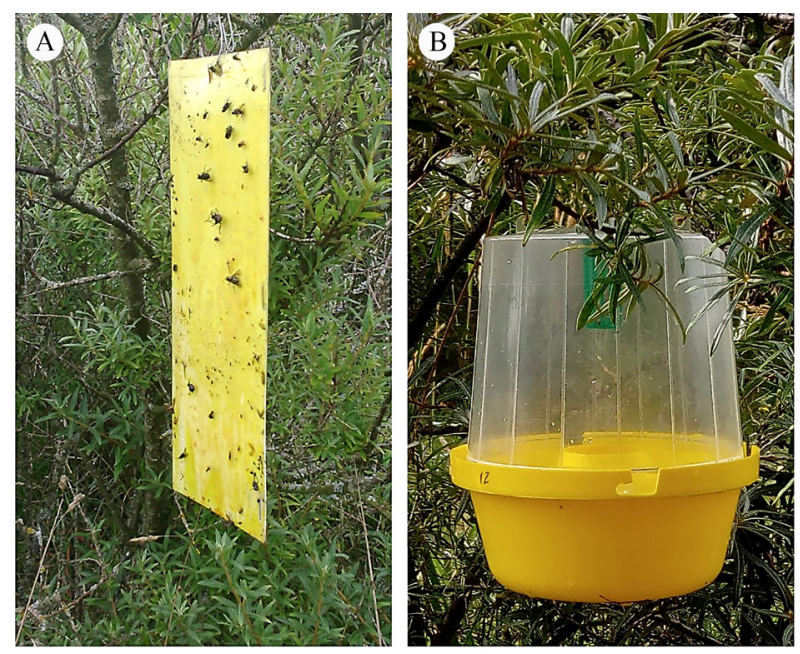

Figure 1. Types of traps: flat sticky (A) and McPhail (B)

The traps of both types were hung on masculine bushes only. The traps were arranged in three groups, each containing a couple of both type traps. The distance between the traps was not less than $2 \mathrm{~m}$, between the groups not less than $20 \mathrm{~m}$. The traps were inspected and rotated regularly with 3 to 4 days' intervals. Trapped fruit flies were counted and identified as Rhagoletis batava Hering, 1938 (Korneyev et al., 2017). Sticky traps were replaced when the surface was contaminated; water solution was either added or replaced in McPhail traps. Sex of trapped $R$. batava (Diptera: Tephritidae) flies was identified based on the presence or absence of ovipositor. Trapping was carried out in July and August 2016, catches were counted 11 times with 3 to 4 days' intervals.
Flight season. To establish flight season, McPhail traps were used (Fig. 1B). Data were collected from June to August 2016, 2017 and 2018. Three traps were hung on masculine bushes in 2016, 2017 and five on feminine bushes in 2018. The distance between the traps was at least $20 \mathrm{~m}$. The catches were recorded with 3 to 4 days' intervals.

Mating period. To establish mating period, a single $50 \mathrm{~m}$ long transect was chosen in buckthorn plantation. All mating $R$. batava couples we recorded while walking through the distance in $15 \mathrm{~min}$. The couples were recorded both on bushes and grasses. Observations and records were started at $9 \mathrm{AM}$ and lasted until 8 PM with 1-hour intervals during 7 days in June and July 2015, with 3 to 4 days' intervals. There was no rainfall during this period and average hourly temperature fluctuated from $18^{\circ} \mathrm{C}$ to $24^{\circ} \mathrm{C}$ during the observations (data from Lithuanian Meteorological Service, Molètai station, located at N lat. 55.235230, E long. 25.416350).

Statistical analysis. All catches were counted and the number of insects trapped per day was calculated. The data were statistically analysed with the software Statistica, version 8.0 (StatSoft Inc., USA). Results of catches on buckthorns of different gender were evaluated by Mann-Witney $U$ test (Čekanavičius, Murauskas, 2008). The same test was applied for statistical evaluation of catches in traps of different design. Catches in traps of different colours were transformed using $(\mathrm{x}+0.5)^{1 / 2}$ and evaluated by Duncan's analysis of variance (ANOVA, Post-hoc) test (Bewick et al., 2004). Statistical significance of difference in ratio of males to females trapped was evaluated by Wilcoxon Matched Pairs test. Flight and mating dynamics was evaluated by comparing statistical difference between recorded values of neighbouring data points by means of Fisher LSD (ANOVA, Post-hoc) test (Čekanavičius, Murauskas, 2008). Statistically significant difference was established when $p$ was equal or less than 0.05 .

\section{Results and discussion}

Seasonal flight dynamics. In 2016 from $30^{\text {th }}$ June to $8^{\text {th }}$ August, $82 R$. batava flies trap ${ }^{-1}$ were recorded with a statistically significant peak from $14^{\text {th }}$ to $18^{\text {th }}$ of July (Fig. 2). In 2017, trapping was started on $11^{\text {th }}$ July and stopped on $22^{\text {nd }}$ August; however, no flies were recorded until $21^{\text {st }}$ July. In total, 26.3 fruit flies trap ${ }^{-1}$ were captured on average. Flight peak was not clearly expressed and based on statistics lasted from $28^{\text {th }}$ July to $18^{\text {th }}$ August. In 2018 , from $26^{\text {th }}$ June to $9^{\text {th }}$ July, $71 R$. batava flies trap $^{-1}$ were recorded with a statistically significant peak from $20^{\text {th }}$ to $24^{\text {th }}$ of July.

It should be noted that the abundance of $R$. batava population during three successive years fluctuated greatly, and based on the seasonal catches differed approximately more than three times.

In Lithuania, seasonal period of adult flight of the species lasted a bit more than one month. The flight started at the beginning of July and lasted until the first ten-day period of August in 2016, and from the second ten-day period of July until the end of August in 2017. In 2018, flight dynamics was similar to that in 2016. Flight lasted from the end of June until the first tenday period of August. The summarised results of the three experimental years suggest that the flight period 


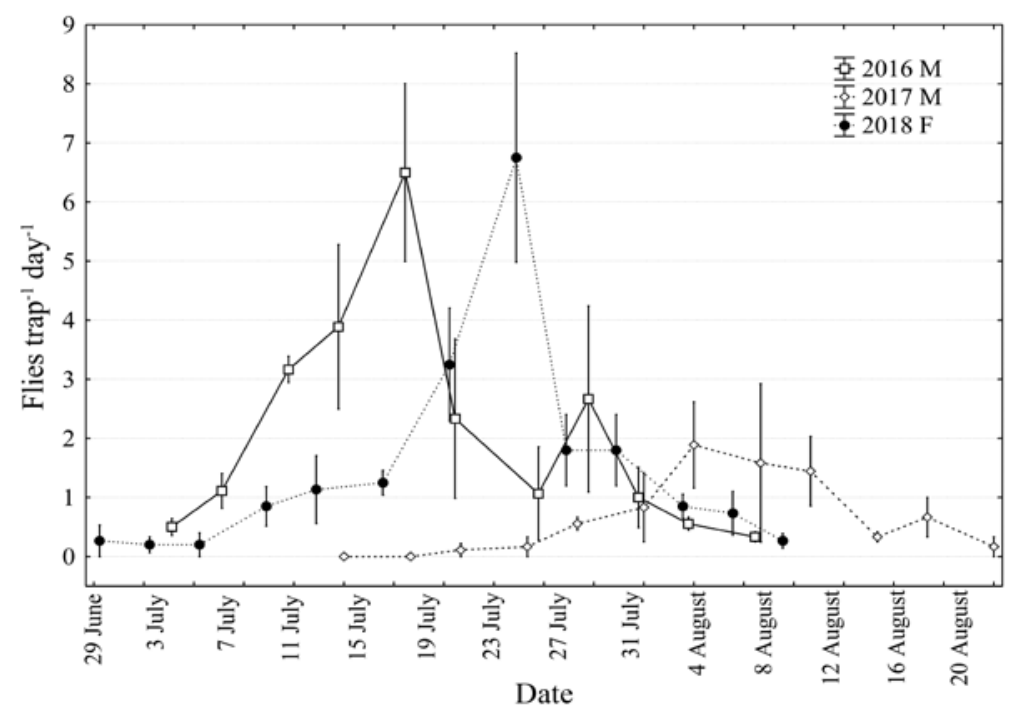

Note. Vertical bars indicate standard error of the mean; $\mathrm{M}$ - traps hung on masculine bushes, $\mathrm{F}$ - on feminine bushes.

Figure 2. Seasonal dynamics of Rhagoletis batava catches

of $R$. batava adults lasted from the very end of June to August. Flight peak was reached between the middle of July and middle of August in the Lithuanian population. Such annual fluctuations of flight period were most likely caused by the differences in the weather conditions.

The total duration of $R$. batava flight period established in the present study, is close to that recorded in Germany (Toth et al., 2016) and differs from that reported in Mongolia and Russia (Siberia, Asian part), where flight period starts 2-3 weeks earlier (Shamanskaya, 2015; Zhao et al., 2017).

Rhagoletis batava catches on buckthorns of different gender. Catches by sticky traps placed on feminine and masculine buckthorn plants differed nearly twice and the difference was statistically significant $(\mathrm{Z}=-3.972, p<0.001)$. The catches on feminine plants exceeded those on masculine ones (Fig. 3). This might be the result of unequal distribution of larvae and cocoons, thus emerging adults. Rhagoletis adults are relatively good flyers capable of covering distances up to 500 meters (e.g., Daniel, Grunder, 2012), and their distribution within plantation could become approximately even soon after emergence. However, this was not the case. Thus, we assume that attractiveness of sea buckthorn plants of different genders differs for adult $R$. batava fruit flies. The reasons for these differences remain to be investigated in the future.

R. batava catches in traps of different colours. Catches in sticky traps of different colour revealed differences in their attractiveness to $R$. batava fruit flies. Captures differed statistically significantly in the three groups of colour traps tested. The group of blue, red, black and transparent traps was the least attractive. Approximately 2.4-5.3 times more attractive were green and white traps. Yellow traps with most abundant captures were the most attractive. The latter traps were approximately 4.3-7.8 times more attractive compared to the first group (Fig. 4). The results obtained in the present study which demonstrated the highest attractiveness of yellow traps agree with those obtained for other fruit flies from genus Rhagoletis, which were the most attracted to yellow traps (Agee et al., 1982; Yee, 2011). Besides, it

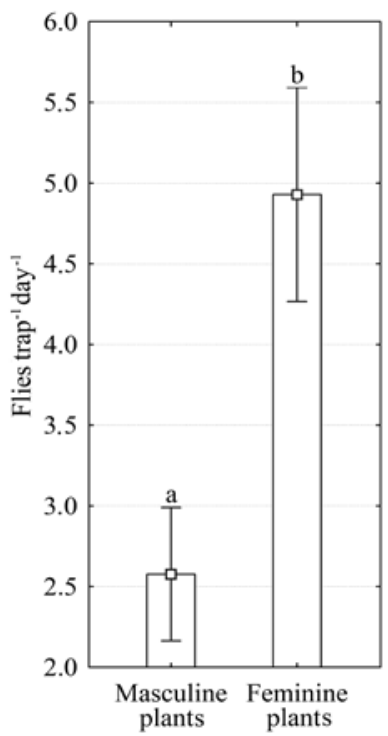

Note. Different letters indicate statistically significant difference; vertical bars indicate standard error of the mean.

Figure 3. Catches of Rhagoletis batava flies on sticky traps hung on masculine and feminine sea buckthorn plants

should be noted that white and green colours, which were less attractive to $R$. batava compared to yellow, contain component of yellow colour within their spectrum. In our opinion, this might explain their relatively higher effectiveness compared to that of the rest (but not yellow) of the colour traps tested, which were significantly less attractive.

Thus, yellow traps are the most suitable for $R$. batava trapping.

Catches of R. batava by traps of different type. Effectiveness. On sticky traps, average catches were 7.2 \pm 1.2 flies per day, and in McPhail traps those were 2.1 \pm 0.4 (Fig. 5). The difference was statistically significant $(\mathrm{Z}=-3.779, p<0.001)$. Thus, the effectiveness of sticky traps was approximately 2.9 times higher compared to that of McPhail traps. Our experience in maintaining 


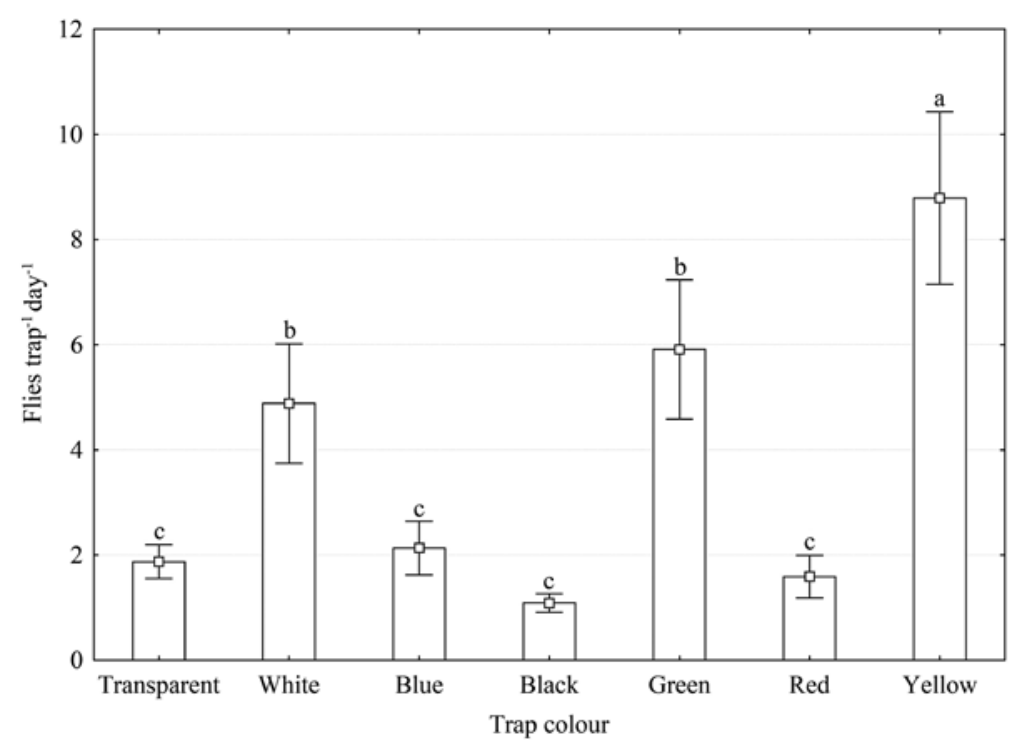

Note. Different letters indicate statistically significant difference; vertical bars indicate standard error of the mean.

Figure 4. Catches of Rhagoletis batava flies by traps of different colour

both sticky and McPhail traps under field conditions suggests that the effectiveness of sticky traps changes in time as their surface is covered with dust, small parts of plants and insects. Sticky area decreases as well as visibility of the colour from a distance (Navarro-Llopis, Vacas, 2014). Thus, in the long run high effectiveness decreases to minimal, if traps are checked and replaced quite rarely. Maintenance of high effectiveness leads to increased service costs. Trapping ability of McPhail traps remains nearly the same for a long time. It allows the user to count insects and refill water (solution) within the traps with longer intervals.

Sex ratio. Attractiveness of sticky and McPhail traps to $R$. batava flies differed between the sexes. The proportion of females was higher in McPhail traps compared to that in sticky ones. Among the 296 of $R$. batava flies trapped by McPhail traps 129 were males and 167 females (the difference was significant, $Z=2.257$, $p=0.02)$, while the catches in sticky traps contained 369 males and 357 females $(Z=0.281, p=0.78)$. Thus the ratio of males to females was approximately equal to $1: 1.3$ and $1: 1$, respectively. Higher proportion of females in catches is important as females cause damage and ensure spreading of the pest towards new territories and newly established plantations. The notable drawback of McPhail trap is the price per unit which is much higher compared to that of sticky trap.

Diurnal rhythm of mating. Mating of $R$. batava flies was recorded during all light period of a day from 9 AM till 8 PM. In total, there were counted 1847 pairs in copula, most of them within time interval from $10 \mathrm{AM}$ to $7 \mathrm{PM}$ with no clear peak in mating activity (Fig. 5). Significantly fewer mating couples were counted at 9 AM and at $8 \mathrm{PM}$. The middle of the active mating period was around $1 \mathrm{PM}$. The air temperature within the range from $18^{\circ} \mathrm{C}$ to $24^{\circ} \mathrm{C}$ (Fig. 5) had no clearly pronounced

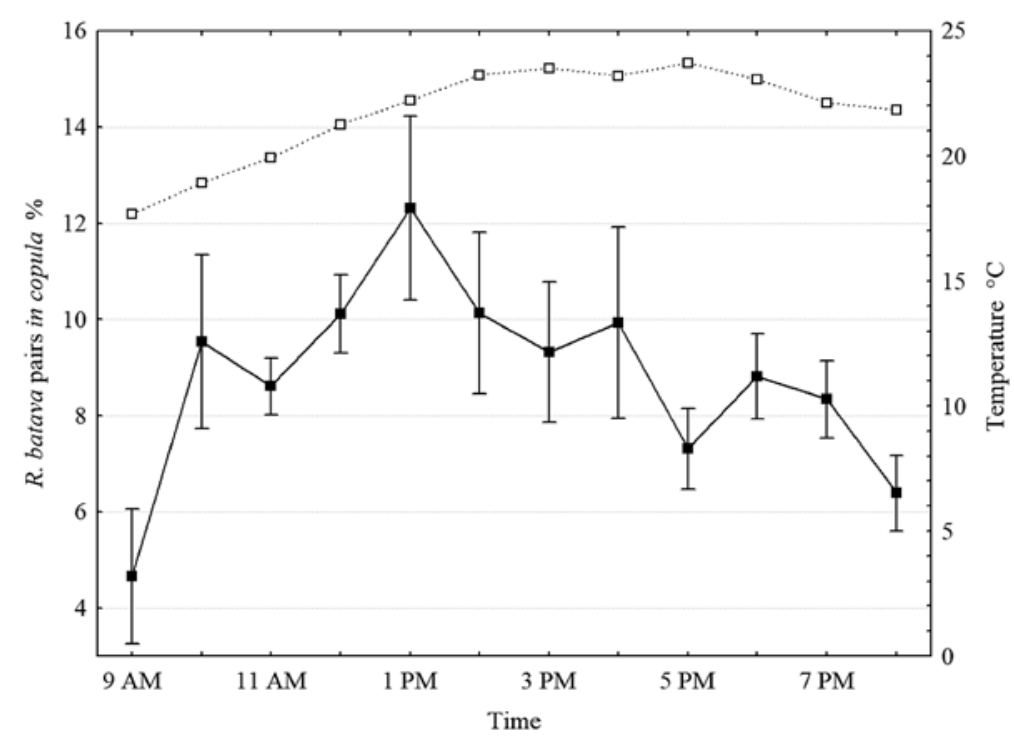

Note. Vertical bars indicate standard error of the mean; black square indicates couples; white square indicates air temperature.

Figure 5. Diurnal rhythm of Rhagoletis batava mating 
effect on the mating activity. Comparison of our data with those previously obtained in Mongolian $R$. batava population (Zhao et al., 2017) reveals both similarities and differences.

The total duration of $R$. batava daily mating period in Mongolia (Zhao et al., 2017) corresponded to that recorded for the flies of Lithuanian population. However, in Mongolian R. batava population there were recorded two peaks of daily mating activity, which does not agree with our findings. Unfortunately, the authors of the mentioned paper made no statistical analysis. Thus, we conclude that daily mating period of $R$. batava flies is long and lasts during all light period of a day with no clear peak. The peak on any specific day might appear under special weather conditions.

\section{Conclusions}

1. Annual flight period of fruit flies Rhagoletis batava lasts approximately six weeks. It starts at the very end of June and ceases in August with a peak from the middle of July till the middle of August on average. Both beginning of the flight period and peak activity may vary by about 20 days between years.

2. Traps deployed on feminine sea buckthorn bushes capture approximately $50 \%$ more $R$. batava flies compared to those deployed on masculine ones.

3. Trap colour is important for $R$. batava fruit flies. The most attractive is yellow with catches $1.5-7.8$ times more abundant compared to the 6 other colours tested.

4. The proportion of $R$. batava females caught by McPhail traps is higher compared to that caught by sticky traps.

5. Mating of $R$. batava fruit flies lasts during all light period of a day without a clearly pronounced peak.

\section{Acknowledgements}

The authors would like to thank Mr. Povilas Šukys for kind permission to carry out field research in his sea buckthorn plantation. The research was cofunded from the EU Structural Funds, project No. 09.3.3-LMT-K-712-01-0099.

Received 27072018 Accepted 09112018

\section{References}

1. Agee H. R., Boller E., Remund U., Davis J. C., Chambers D. L. 1982. Spectral sensitivities and visual attractant studies on the Mediterranean fruit fly, Ceratitis capitata (Wiedemann), olive fly, Dacus oleae (Gmelin), and the European cherry fruit fly, Rhagoletis cerasi (L.) (Diptera, Tephritidae). Zeitschrift für Angewandte Entomologie, 93: 403-412. https://doi.org/10.1111/j.1439-0418.1982.tb03612.x

2. Bal L. M., Meda V., Naik S. N., Satya S. 2011. Sea buckthorn berries: a potential source of valuable nutrients for nutraceuticals and cosmeceuticals. Food Research International, 44 (7): 1718-1727.

https://doi.org/10.1016/j.foodres.2011.03.002

3. Bewick V., Cheek L., Ball J. 2004. Statistics review 9: oneway analysis of variance. Critical Care, 8: 130-136. https://doi.org/10.1186/cc2836
4. Čekanavičius V., Murauskas G. 2008. Statistika ir jos taikymas II (in Lithuanian).

5. Daniel C., Grunder J. 2012. Integrated management of European cherry fruit fly Rhagoletis cerasi (L.): situation in Switzerland and Europe. Insects, 3 (4): 956-988. https://doi.org/10.3390/insects3040956

6. Korneyev V. A., Mishustin R. I., Korneyev S. V. 2017. The Carpomyini fruit flies (Diptera: Tephritidae) of Europe, Caucasus, and Middle East: new records of pests, with improved keys. Vestnik zoologii, 51 (6): 453-470. https://doi.org/10.2478/vzoo-2017-0056

7. Li T. S. C., Schroeder W. R. 1996. Sea buckthorn (Hippophae rhamnoides L.): a multipurpose plant. HortTechnology, 6 (4): 370-380. https://doi.org/10.21273/HORTTECH.6.4.370

8. Mohamadzade Namin S., Rasoulian G. R. 2009. A review of fruit flies of the genus Rhagoletis (Diptera, Tephritidae) of Iran and bordering countries, with the key to species. Vestnik zoologii, 43 (1): e-25-e-30. https://doi.org/10.2478/v10058-009-0003-0

9. Navarro-Llopis V., Vacas S. 2014. Mass trapping for fruit fly control. Shelly T. et al. (eds). Trapping and the detection, control, and regulation of tephritid fruit flies. Springer, p. 513-555.

https://doi.org/10.1007/978-94-017-9193-9_15

10. Ruan C.-J., da Silva J. A. T., Jin H., Li H., Li D.-Q. 2007. Research and biotechnology in sea buckthorn (Hippophae spp.). Medicinal and Aromatic Plant Science and Biotechnology, 1 (1): 47-60.

11. Shalkevich M. S., Koltun N. Y., Pleskatsevich R. I. 2015. Sea buckthorn pests and diseases in Belarus. Proceedings of the $3^{\text {rd }}$ European workshop on sea buckthorn EuroWorkS2014. Naantali, Finland, p. 83-86.

12. Shamanskaya L. D. 2015. Bioecology of the sea-buckthorn fly (Rhagoletis batava obscuriosa Kol.) and pest control treatment in Altai. Proceedings of the $3^{\text {rd }}$ European workshop on sea buckthorn EuroWorkS2014. Naantali, Finland, p. 7-20.

13. Stalažs A. 2014 (a). New records of some dipterans (Diptera: Cecidomyidae, Tephritidae) in north-eastern Lithuania, Zoology and Ecology, 24 (1): 55-57. https://doi.org/10.1080/21658005.2014.883831

14. Stalažs A. 2014 (b). New records of Tephritoidea (Diptera: Brachycera) for the fauna of Latvia, Zoology and Ecology, 24 (4): 347-351.

https://doi.org/10.1080/21658005.2014.939883

15. Stalažs A., Balalaikins M. 2017. Country checklist of Rhagoletis Loew (Diptera: Tephritidae) for Europe, with focus on $R$. batava and its recent range expansion. Proceedings of the Latvian Academy of Sciences, 71 (3): 103-110. https://doi.org/10.1515/prolas-2017-0018

16. Toth M., Voigt E., Baric B., Pajac I., Subic M., Baufeld P., Lerche S. 2014. Importance of application of synthetic food lures in trapping of Rhagoletis spp. and Strauzia longipennis Wiedemann. Acta Phytopathologica et Entomologica Hungarica, 49 (1): 25-35. https://doi.org/10.1556/APhyt.49.2014.1.3

17. Toth M., Lerche S., Holz U., Kerber A., Henning R., Voigt E., Kelemen D. 2016. Addition of synthetic feeding attractant increases catches of Rhagoletis batava Hering and Carpomyia schineri Loew. in fluorescent yellow sticky traps. Acta Phytopathologica et Entomologica Hungarica, 51 (1): 69-76. https://doi.org/10.1556/038.51.2016.1.6

18. Yee W. L. 2011. Evaluation of yellow rectangle traps coated with hot melt pressure sensitive adhesive and sticky gel against Rhagoletis indifferens (Diptera: Tephritidae). Journal of Economical Entomology, 104 (3): 909-919. https://doi.org/10.1603/EC10327 
19. Yee W. L. 2012. Preferences by Rhagoletis indiffe rens (Diptera, Tephritidae) for rectangles of various yellow colours and fluorescence. Journal of Applied Entomology, 137 (3): 225-233. https://doi.org/10.1111/j.1439-0418.2012.01725.x

20. Yee W. L. 2013. Captures of Rhagoletis indifferens (Diptera: Tephritidae) and nontarget insects on red spheres versus yellow spheres and panels. Journal of Economic Entomology, 106 (5): 2109-2117. https://doi.org/10.1603/EC12501
21. Yee W. L., Goughnour R. B. 2011. Differential captures of Rhagoletis pomonella (Diptera: Tephritidae) on four fluorescent yellow rectangle traps. The Florida Entomologist, 94 (4): 998-1009. https://doi.org/10.1653/024.094.0438

22. Zhao B., Su Z., Li Sh., Men J., Cheng T., Wei J. 2017. Biological characteristics of Rhagoletis batava boseuriosa (Diptera: Tephritidae). Forest Research, 30 (4): 576-581 (in Chinese).

ISSN 1392-3196 / e-ISSN 2335-8947

Zemdirbyste-Agriculture, vol. 106, No. 1 (2019), p. 81-86

DOI 10.13080/z-a.2019.106.011

\title{
Dygliuotojo šaltalankio musès (Rhagoletis batava) gaudymo gaudyklèmis ypatumai, skraidymo ir poravimosi dinamika Lietuvoje
}

\author{
D. Aleknavičius, V. Būda
}

Gamtos tyrimų centras

\section{Santrauka}

Šaltalankinè musė (Rhagoletis batava Hering) yra žalingiausias dygliuotojo šaltalankio (Hippophae rhamnoides L.) uogų kenkèjas. Dèl šio kenkejjo šaltalankių augintojai patiria didžiulius derliaus nuostolius. Pastaruoju metu Europoje ši musè sparčiai plinta. Tyrimo tikslas - lauko sąlygomis nustatyti $R$. batava musių sezoninę skraidymo dinamiką, poravimosi aktyvumo paros ritmą ir gaudyklių spalvos bei konstrukcijos įtaką jų sugavimui. Tyrimo metu nustatyta, kad $R$. batava musėms svarbi gaudyklès spalva - jų daugiausia jų sugauta geltonos spalvos gaudyklėmis. Jomis šio kenkèjo pagauta 1,5-7,8 karto daugiau nei kitų testuotų spalvų gaudyklėmis. Lietuvoje $R$. batava skraidymo laikotarpis prasideda birželio pabaigoje ir baigiasi rugpjūčio mènesị, jo trukmė - maždaug 6 savaitès. Didžiausias skraidymo aktyvumas trunka nuo liepos vidurio iki rugpjūčio vidurio. İvairiais metais skraidymo laikotarpis, pradžia ir didžiausias skraidymo aktyvumas gali svyruoti ne mažiau nei 20 dienų intervalu. $R$. batava poruojasi visu šviesiuoju dienos metu, be ryškaus aktyviausio poravimosi laikotarpio. Tarp „McPhail“ gaudyklemis pagautų $R$. batava musių patelių dalis yra didesnè nei tarp pagautų lipniomis gaudyklèmis. Gaudyklèmis $R$. batava musių šaltalankio moteriškuose krūmuose pagaunama maždaug 50 \% daugiau nei vyriškuose.

Reikšminiai žodžiai: gaudyklès efektyvumas, gaudyklès spalva, kenkèjo stebëjimas, poravimosi paros ritmas, skraidymo trukmè, vaisinè musè. 